Terakreditasi: SK No.: 60/E/KPT/2016

Website : http://ejournal.undip.ac.id/index.php/reaktor/

Reaktor, Vol. 17 No. 1, Maret Tahun 2017, Hal. 25-35

\title{
Pembuatan Selulosa Terasetilasi dari Pulp Bambu Betung (Dendrocalamus asper) serta Pengaruhnya Terhadap Sifat Mekanis Biokomposit Polipropilena
}

\author{
Wida Banar Kusumaningrum ${ }^{1,2, *)}$, Rochmadi' ${ }^{1)}$, dan Subyakto ${ }^{2)}$ \\ ${ }^{1)}$ Departemen Teknik Kimia, Fakultas Teknik, Universitas Gadjah Mada \\ Jl. Grafika No. 2, Yogyakarta \\ 2) Pusat Penelitian Biomaterial LIPI \\ Jl. Raya Bogor Km. 46, Cibinong, Bogor \\ ${ }^{*}$ Penulis korespondensi: wida.banar@biomaterial.lipi.go.id
}

\begin{abstract}
ACETYLATED CELLULOSE FROM BETUNG BAMBOO (Dendrocalamus asper) PULP PRODUCTION AND ITS EFFECT ON MECHANICAL PROPERTIES OF POLYPROPYLENE COMPOSITES. The utilization of natural fiber as reinforcing agent for biocomposite products have some drawbacks, such as its hydrophilicity that are incompatible with $P P$. Isolation from bundle fibers into micro fibers could improves the biocomposite properties. However, more moisture absorption of micro fiber makes it difficult to handle. Therefore, modification with acetylation is needed to facilitate good interfacial adhesion between cellulose and PP. The objectives of this research are to obtain acetylated micro fibers from betung bamboo pulp for reinforcing agent and to investigate the effect of acetylated cellulose on mechanical properties of PP biocomposites. Acetate anhydride as acetylating agent and sulfuric acid as a catalyst were used for acetylation process. Acetylated cellulose from betung bamboo pulp with fibrous form, hydrophobic condition, and relatively on high aspect ratio was obtained in $2 \%$ of catalyst concentration and 120 of reaction time. Strength enhancement were achieved up to 79 and $87 \%$ for tensile while 24 and $69 \%$ for flexural, respectively for biocomposites with $10 \%$ and $20 \%$ of acetylated cellulose than that PP. Modulus improvement were obtained up to 53 and 70\% for tensile while 96 and 149\% for flexural, respectively for biocomposites with $10 \%$ and $20 \%$ of acetylated cellulose than that $P P$.
\end{abstract}

Keywords: acetylation; betung bamboo; biocomposite; polypropylene; cellulose

\begin{abstract}
Abstrak
Penerapan serat alam untuk produk biokomposit memiliki beberapa kelemahan terutama perbedaan sifat antara matrik dengan serat yang menyebabkan ikatan antar muka yang kurang baik. Pengolahan serat bundle menjadi serat mikro dapat meningkatkan sifat-sifat biokomposit, akan tetapi sifat dari serat mikro yang mudah menyerap air membuat penanganannya menjadi lebih komplek. Modifikasi kimia serat dengan asetilasi merupakan upaya untuk meningkatkan keterbasahan dan ikatan antar muka dengan matrik PP. Tujuan dari penelitian ini adalah untuk memperoleh serat mikro terasetilasi dari pulp bambu betung agar dapat digunakan sebagai penguat dan mempelajari pengaruhnya terhadap sifat mekanis biokomposit PP. Proses asetilasi menggunakan asetat anhidrat sebagai bahan pengasetilasi dan asam sulfat sebagai katalis. Serat mikro bambu betung terasetilasi yang bersifat hidrofobik dan memiliki aspek rasio tinggi diperoleh pada jumlah katalis 2\% dengan waktu 120 menit. Peningkatan kuat tekuk mencapai 76 dan 87\% sedangkan kuat tarik sekitar 24 dan 69\% masing-masing untuk biokomposit dengan selulosa terasetilasi 10\% dan 20\% terhadap PP murni.
\end{abstract}


Keteguhan tarik meningkat hingga 53 dan 70\% sedangkan keteguhan tekuk mencapai 96 dan 149\% berturut-turut untuk biokomposit dengan 10\% dan 20\% selulosa terasetilasi dibandingkan PP. Selulosa terasetilasi dari pulp bambu betung mampu berfungsi sebagai bahan pembentuk inti untuk biokomposit PP.

Kata kunci: asetilasi; bambu betung; biokomposit; polipropilena; selulosa

How to Cite This Article: Kusumaningrum, W.B., Rochmadi, dan Subyakto, (2017), Pembuatan Selulosa Terasetilasi dari Pulp Bambu Betung (Dendrocalamus Asper) serta Pengaruhnya Terhadap Sifat Mekanis Biokomposit Polipropilena, Reaktor, 17(1), 25-35, http://dx.doi.org/10.14710/reaktor.17.1.25-35

\section{PENDAHULUAN}

Produk biokomposit semakin berkembang seiring dengan kebutuhan dunia akan material yang ramah lingkungan dan dikategorikan sebagai sustainable material. Berbagai produk komposit telah dikembangkan untuk berbagai industri, antara lain pada komponen otomotif, konstruksi, kelautan, elektronik, dan lain-lain. Industri otomotif merupakan pengguna produk biokomposit terbesar. Hal ini terkait dengan diberlakukannya ketentuan $95 \%$ material otomotif dapat terdegradasi di alam (biodegradable) oleh End of Live Vehicle (ELV). Sebagai tindak lanjutnya, beberapa negara menerapkan berbagai kebijakan, seperti Eropa yang menetapkan 85\% komponen kendaraan harus dapat digunakan kembali (reuse) dan didaur ulang (recycle) pada 2015 dan Jepang yang menetapkan 95\% komponen kendaraan harus dapat terdegradasi di alam pada 2015 (Holbery dan Houston, 2006). Penggunaan serat alam telah diaplikasikan pada lebih dari 50 komponen interior dan eksterior mobil. Sumber serat yang digunakan pada komponen tersebut merupakan serat bundle dari beberapa jenis serat yang sudah komersial seperti jute, hemp, flax, sisal, dan kelapa yang memiliki keunggulan pada sifat mekanis untuk menggantikan serat gelas yang sebelumnya mendominasi industri otomotif sebagai penguat komposit.

Penerapan serat alam dalam industri otomotif masih berupa serat panjang yang disebut serat bundle (Hufenbagh dkk., 2011). Serat bundle terdiri dari beberapa serat tunggal yang secara umum terdiri dari selulosa, hemiselulosa, dan lignin. Selulosa memiliki struktur kristalin, sementara hemiselulosa dan lignin memiliki struktur amorf (Joonobi dkk., 2009). Komponen utama serat adalah holoselulosa (selulosa dan hemiselulosa) yang memiliki gugus hidroksil sehingga bersifat polar hidrofilik dan mudah berikatan dengan air. Oleh karena itu, pengolahan serat alam sebagai penguat pada komposit menjadi sangat komplek. Pencampuran antara polimer yang bersifat nonpolar hidrofobik dengan serat yang bersifat polar hidrofilik menjadi tantangan tersendiri karena ikatan antar muka yang kurang baik.

Menurut Zimmermann dkk. (2004), secara hirarki serat bundle tersusun atas beberapa serat tunggal dimana dalam serat tunggal terdiri dari beberapa serat mikro hingga nano sampai pada bagian terkecil adalah susunan selulosa yang bersifat kristalin. Serat tunggal dapat diisolasi melalui proses pembuatan pulp dimana akan diperoleh serat dengan keteguhan $40 \mathrm{GPa}$, kekuatan $400 \mathrm{MPa}$, dan diameter serat lebih dari $100 \mu \mathrm{m}$. Serat mikro dapat diperoleh melalui proses mekanis atau kimia dimana dapat diperoleh serat dengan keteguhan $70 \mathrm{GPa}$, kekuatan $700 \mathrm{MPa}$, dan diameter 1-100 $\mu \mathrm{m}$. Sementara itu pemrosesan hingga mencapai serat nano dengan struktur kristal dapat menghasilkan serat dengan keteguhan 130-250 GPa, kekuatan 80-10.000 MPa. Pengolahan serat bundle menjadi serat mikro (MFC) disebabkan karena MFC menghasilkan komposit dengan kuat tarik mencapai 5x lipat, dari 164 menjadi $700 \mathrm{MPa}$, sedangkan modulus meningkat dari 2 menjadi $70 \mathrm{GPa}$ karena peningkatan aspect ratio (Kompella dan Lambros, 2002; Zimmerman dkk., 2004).

Sifat MFC yang mudah menyerap air menyebabkan sulit digunakan untuk proses kering pada pembuatan biokomposit. Tanpa pengeringan fisik yang baik, dimungkinkan akan terjadi ikatan hidrogen antar serat yang menyebabkan serat saling berikatan dan menggumpal (aglomerasi) sebelum digunakan sebagai matrik pada komposit. Untuk menghindari aglomerasi MFC, perlu adanya teknik pengeringan seperti freeze drying, spray drying, supercritical drying yang saat ini masih relatif sulit dilakukan dengan konsumsi energi cukup besar (Abdul, 2014). Oleh karena itu, diperlukan modifikasi permukaan yang dapat membatasi penyerapan air pada MFC. Salah satu proses yang dapat memberikan sediaan MFC dalam bentuk kering dengan pengurangan ikatan gugus hidroksil pada serat serta peningkatan keterbasahan (wettability) adalah dengan modifikasi kimia permukaan serat. Beberapa metode modifikasi kimia diantaranya perlakuan alkali, silane, asetilasi, dan benzoilasi (Li dkk., 2007; Thielemans dkk., 2008). Menurut Abdul (2014), proses asetilasi menghasilkan ikatan antar muka yang lebih baik dengan perbaikan kekuatan daripada dengan perlakuan silane dan alkali karena pembentukan senyawa ester. Gambar 1 menunjukkan reaksi umum asetilasi pada serat.

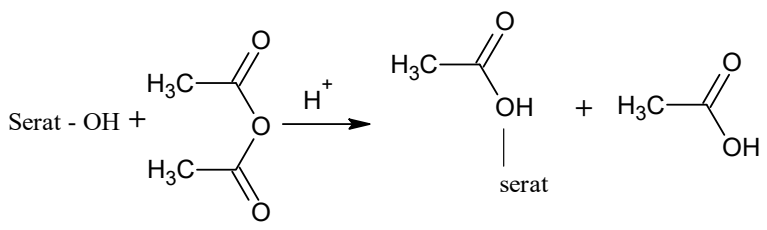

Gambar 1. Reaksi asetilasi permukaan serat bambu betung dengan asetat anhidrat 
Indonesia kaya akan sumber serat alam yang dapat diekstrak dari berbagai jenis tanaman baik kayu maupun non-kayu. Akibat deforestrasi hutan, tanaman cepat tumbuh seperti bambu menjadi alternatif pengganti serat dari sumber non-kayu. Saat ini serat bambu banyak dimanfaatkan untuk kerajinan, alat musik, struktural, dan juga tekstil. Sebagai sumber serat, bambu dalam bentuk bundle memiliki kandungan selulosa sebesar $60,8 \%$ dan lignin 32,2\% dengan kekuatan berkisar 140-800 MPa (Liu dkk., 2012). Sementara itu serat bambu betung memiliki komposisi holoselulosa (selulosa dan hemiselulosa) sebesar 83,3\% dengan kandungan lignin sekitar 30,21\% (Fatriasai dan Hermiati, 2008). Komposisi kimia serat tersebut mendekati serat hemp dan sisal dengan kandungan selulosa masing-masing adalah 68\% dan 60\% (Al-Oqla dan Sapuan, 2014).

Polipropilena (PP) merupakan polimer termoplastik yang memiliki kegunaan yang cukup luas untuk berbagai macam produk. PP memiliki densitas rendah, stabilitas dimensi dan sifat mekanis yang baik, serta nilai impak yang cukup tinggi (Holbery dan Houston, 2006). Oleh karena itu, PP banyak digunakan sebagai komponen otomotif seperti dalam komponen mobil yang dapat mencapai 32\% (Al-Oqla dan Sapuan, 2014).

Modifikasi kimia selulosa dari MFC dengan proses asetilasi telah dilakukan dengan kondisi operasi di bawah suhu ruang $0-25^{\circ} \mathrm{C}$ dan menghasilkan selulosa terasetilasi dengan bentuk gel dan serbuk (Widyaningsih dan Radiman, 2007; Yang dkk., 2008; Gaol dkk., 2013). Sementara itu Abdulkhani (2014) menggunakan suhu $100^{\circ} \mathrm{C}$ untuk asetilasi nano MFC. Beberapa faktor yang berpengaruh antara lain suhu, waktu, jumlah pereaktan, dan jumlah katalis. Jumlah katalis sangat berpengaruh terhadap kecepatan reaksi asetilasi pada permukaan serat. Bledzki dkk. (2008) menggunakan katalis asam perklorat dengan jumlah dari 0,026-0,052\% pada serat flax dan menunjukkan sedikit perubahan morfologi pada serat. Sementara itu Zhang dkk. (2013) menggunakan katalis asam sulfat dari $4-9 \%$ dengan suhu operasi $60^{\circ} \mathrm{C}$ memberikan hasil bahwa terjadi kerusakan pada permukaan serat batang padi. Pemanfaatan serat terasetilasi untuk komposit dengan matrik PP telah dilakukan dengan sumber serat yang beragam. Asetilasi pada permukaan serat panjang (bundle) sisal menunjukkan adanya interaksi yang lebih baik dengan matrik PP dibandingkan tanpa perlakuan (Albano dkk., 2003). Peningkatan sifat mekanis juga terjadi pada biokomposit PP dengan serat panjang flax terasetilasi (Bledzki dkk., 2008). Penelitian yang dilakukan oleh Luz dkk. (2008) memberikan hasil yang berbeda dimana serat bagas terasetilasi mengalami perubahan morfologi menjadi partikel sehingga berpengaruh pada penurunan sifat mekanis biokomposit PP. Sebagai penguat pada matrik PP, MFC dengan aspek rasio tinggi lebih diutamakan. Penulis belum menemukan studi asetilasi serat MFC bambu betung yang menghasilkan serat dengan aspek rasio tinggi dan juga penerapannya pada matrik PP. Tujuan penelitian ini adalah untuk menentukan kondisi operasi proses asetilasi pada serat dari pulp bambu betung agar dapat digunakan sebagai penguat dan mempelajari pengaruhnya terhadap sifat mekanis biokomposit PP.

\section{BAHAN DAN METODE Bahan}

Serat bambu betung diperoleh dari pohon bambu koleksi Kebun Raya Bogor, Bogor. Serat bambu betung kemudian diproses menjadi pulp menggunakan metode sulfat (kraft) di Balai Besar Pulp dan Kertas, Bandung. Pemutihan pulp bambu betung menggunakan hidrogen peroksida $\left(\mathrm{H}_{2} \mathrm{O}_{2}\right)$ teknis dengan kadar 50\%. Bahan kimia yang digunakan untuk proses asetilasi pulp dan analisis antara lain asam asetat PA dengan kadar 99,9\%, asam asetat anhidrat PA dengan kadar 99,9\%, asam sulfat PA dengan kadar 99,6\%, etanol PA dengan kadar 96,6\%, natrium hidroksida PA, hidrogen klorida PA dengan kadar 36\%, etanol teknis kadar 96\%, dan aseton teknis. Semua bahan kimia PA diperoleh dari MERCK Indonesia. Polipropilena yang digunakan sebagai matrik komposit berjenis homopolimer diperoleh dari PT Tripolita, Cilegon.

\section{Metode \\ Pemutihan pulp bambu betung}

Pulp bambu betung belum putih sebanyak 10 gram (berat kering tanur) ditambahkan larutan $\mathrm{H}_{2} \mathrm{O}_{2}$ kadar 50\% sebanyak $60 \mathrm{ml}$. Proses pemutihan dilakukan pada suhu $80^{\circ} \mathrm{C}$ selama 2 jam. Pulp bambu betung yang telah diputihkan kemudian dicuci dengan menggunakan air sampai tidak berbau dan bersih.

\section{Asetilasi pulp bambu betung}

Sebanyak 5 gram pulp bambu betung yang telah diputihkan, diaktivasi menggunakan $100 \mathrm{ml}$ asam asetat glasial pada suhu ruang selama 1 jam. Setelah aktivasi pulp, dilakukan proses asetilasi menggunakan asetat anhidrat dengan katalis asam sulfat pada suhu $60^{\circ} \mathrm{C}$. Penambahan asam asetat anhidrat sebanyak $50 \mathrm{ml}$ dan katalis asam sulfat sebanyak 1, 2, dan 3\% basis berat pulp kering. Proses asetilasi dilakukan selama 1-4 jam. Pencucian bertahap dilakukan setelah proses asetilasi menggunakan aquadest sekitar $1500 \mathrm{ml}$, etanol teknis sebanyak $500 \mathrm{ml}$, dan aseton teknis sebanyak $500 \mathrm{ml}$ berturut-turut hingga diperoleh $\mathrm{pH}$ netral dan serat terasetilasi tidak berbau asam.

\section{Pembuatan biokomposit}

Pelet homopolimer polipropilena (PP) dicampur dengan pulp bambu betung dalam kneader Rheomix Haake Polydrive. Komposisi selulosa yang ditambahkan dalam matrik PP adalah $10 \%$ dan $20 \%$ berdasarkan berat. Pencampuran dilakukan pada suhu $180^{\circ} \mathrm{C}$ selama 15 menit. Hasil pencampuran (compound) dicetak menggunakan hot press pada suhu $180^{\circ} \mathrm{C}$ selama 2 menit dengan tekanan $1 \mathrm{MPa}$. 
Notasi pengkodean untuk biokomposit tanpa perlakuan asetilasi adalah PBB dan dengan perlakuan adalah PAB, sedangkan 10 dan 20 adalah komposisi serat dalam matrik PP.

\section{Analisis komponen kimia}

Komponen kimia pulp bambu sebelum dan sesudah pemutihan dilakukan dengan modifikasi metode TAPPI. Kadar ekstraktif dianalisis menggunakan metode TAPPI T 204 cm-97, kadar lignin dengan TAPPI T 222 om-02, kadar alfa selulosa dengan TAPPI T 203 om-93, sedangkan kadar holoselulosa dengan modifikasi metode Wise dkk. (1946).

\section{Analisis derajat substitusi}

Analisis kadar asetil dan derajat substitusi untuk selulosa terasetilasi merujuk pada analisis yang telah dilakukan Ernest-Saunders dkk. (2014). 100 mg selulosa terasetilasi direndam dalam $10 \mathrm{ml}$ etanol $75 \%$, kemudian dipanaskan pada suhu $60^{\circ} \mathrm{C}$ selama 30 menit. Sampel ditambahkan $\mathrm{NaOH}$ 0,5 N sebanyak 12 $\mathrm{ml}$, kemudian dipanaskan kembali pada suhu $60^{\circ} \mathrm{C}$ selama 15 menit. Sample uji didiamkan pada suhu $25^{\circ} \mathrm{C}$ selama 72 jam sebelum dilakukan analisis. Alkali berlebih ditritasi dengan $\mathrm{HCl} 0,5 \mathrm{~N}$, kemudian ditambahkan $1 \mathrm{ml}$ dan didiamkan selama 24 jam. Titrasi balik untuk menganalisis kelebihan asam dengan $\mathrm{NaOH} 0,5$ N. Perhitungan kadar asetil menggunakan persamaan 1, sedangkan derajat substitusi menggunakan persamaan 2 .

$$
\begin{gathered}
\text { Kadar asetil }(\%)=\frac{[(\mathrm{D}-\mathrm{C})+(\mathrm{A}-\mathrm{B})] \mathrm{N} \times 4,305}{W} \\
\mathrm{DS}=\frac{3,86 \times \text { kadar asetil }(\%)}{102,4-\text { kadar asetil }(\%)}
\end{gathered}
$$

dimana $\mathrm{A}$ adalah volume $\mathrm{NaOH}$ yang digunakan untuk titrasi sample, $\mathrm{B}$ adalah volume $\mathrm{NaOH}$ blangko, $\mathrm{C}$ adalah volume $\mathrm{HCl}$ yang digunakan untuk titrasi sample, $\mathrm{D}$ adalah volume $\mathrm{HCl}$ blangko, $\mathrm{N}$ adalah konsentrasi molar $\mathrm{NaOH}$ dan $\mathrm{HCl}$, dan $\mathrm{W}$ adalah berat sample.

\section{Analisis penyerapan air}

Metode analisis penyerapan air merujuk pada Nwadiogbu dkk. (2014). Pulp bambu sebanyak 100 mg direndam dalam $10 \mathrm{ml}$ aquadest. Setelah perendaman selama waktu 15, 30, dan 60 menit, pulp ditiriskan selama 10 menit kemudian ditimbang. Air yang terserap dihitung dari selisih berat sebelum dan sesudah perendaman.

\section{Fourier Transform Infra Red (FT-IR)}

FT-IR digunakan untuk menganalisis gugusgugus fungsi spesifik untuk selulosa dan biokomposit. Pada penelitian ini menggunakan FT-IR Shimadzu. Transmisi spektrum infra merah pada kisaran panjang gelombang 400-4000 $\mathrm{cm}^{-1}$.

\section{$X$-ray diffraction (XRD)}

Analisis XRD digunakan untuk mendeteksi karaktersitik difraksi selulosa sebelum dan setelah perlakuan dan juga untuk mengetahui karaktersitik biokomposit. XRD Lab-X 6000 Shimadzu digunakan pada penelitian ini. Derajat kristalisasi (\%Xc) dapat diprediksi menggunakan persamaan 3 .

$$
\% X c=\frac{I_{\text {kristalin }}}{I_{\text {kristalin }}+I_{\text {amorf }}} \times 100 \%
$$

dimana $\mathrm{I}_{\text {kristalin }}$ menunjukkan intensitas fase kristalin dengan sudut $2 \theta=22-23^{\circ}$, sedangkan $I_{\text {amorf }}$ menunjukkan intensitas fase amorf dengan sudut $2 \theta=18-19^{0}$

\section{Analisis morfologi}

Analisis morfologi dilakukan dengan menggunakan Mikroskop Optik Olympus CX21 dan Scanning Electron Microscope (SEM) Hitachi TM3030. Kedua alat analisis tersebut digunakan untuk menganalisis perubahan morfologi pada serat setelah dan sebelum perlakuan asetilasi serta analisis uji kegagalan (fracture) pada biokomposit. Sebelum analisis menggunakan SEM, sample terlebih dahulu dilapisi dengan emas. Scanning electron dilakukan pada gelombang $5 \mathrm{kV}$.

\section{Differential Scanning Calorimetry (DSC)}

DSC Perkin Elmer Phyris 1 DC4000 yang dilengkapi intercooler digunakan pada penelitian ini. Karaktersitik sifat panas serat bambu betung dianalisis menggunakan DSC dengan kecepatan pemanasan $10^{\circ} \mathrm{C} /$ menit dari suhu 30 sampai $400^{\circ} \mathrm{C}$.

\section{Sifat mekanis biokomposit}

Karakteristik sifat mekanis dilakukan dengan Universal Testing Machine (UTM) Shimadzu. Pengujian sifat mekanis berdasarkan ASTM D-638 untuk analisis kuat tarik dan ASTM D-790 untuk analisis kuat tekuk. Crosshead speed yang digunakan untuk pengujian adalah $5 \mathrm{~mm} /$ menit.

\section{HASIL DAN PEMBAHASAN}

\section{Komponen Kimia Pulp Bambu Betung}

Komponen utama penyusun serat alam meliputi selulosa, hemiselulosa, dan lignin. Selulosa memiliki sifat kristalin sementara hemiselulosa dan lignin bersifat amorf yang lebih mudah larut dalam pelarut alkali dan asam. Perbedaan sifat tersebut juga berpengaruh pada penentuan proses asetilasi. Kecepatan difusi dan reaktifitas komponen amorf lebih tinggi dibandingkan dengan komponen kristalin, karena gugus hidroksil bebas pada komponen amorf, tanpa ikatan hidrogen, lebih mudah terakses oleh bahan pengasetilasi daripada pada komponen kristalin (Yang dkk., 2008). Beberapa studi menyebutkan bahwa hemiselulosa dan lignin memiliki kecepatan reaksi asetilasi yang lebih cepat dibandingkan selulosa dan meningkat seiring dengan peningkatan komposisinya dalam serat (Ramsden dan Blake, 1997; 
Popescu dkk., 2012). Hal tersebut tidak diharapkan pada reaski asetilasi selulosa karena katalis akan bereaksi terlebih dahulu dengan komponen amorf sehingga dapat menghambat subtitusi gugus asetil pada selulosa. Oleh karena itu, perlakuan pendahuluan diperlukan untuk mengurangi komponen amorf dalam serat.

Salah satu proses yang dapat digunakan untuk mendegradasi komponen amorf adalah dengan pemutihan atau delignifikasi. Proses delignifikasi dapat dilakukan dengan reaksi oksidasi oleh senyawa oksidator kuat seperti hidrogen peroksida $\left(\mathrm{H}_{2} \mathrm{O}_{2}\right)$. Anion perhidroksil $\left(\mathrm{OOH}^{-}\right)$yang diperoleh dari dekomposisi $\mathrm{H}_{2} \mathrm{O}_{2}$ pada kondisi tertentu dapat memutus ikatan fenol terkonjugasi, $90 \%$ struktur lignin merupakan unit fenolik, pada senyawa kromofor menjadi ikatan tunggal yang tidak menyerap warna (Wildan, 2010). Sementara itu, penambahan $\mathrm{NaOH}$ akan memberikan suasana basa pada proses oksidasi sekaligus meluruhkan hemiselulosa yang mudah larut dalam pelarut alkali karena tersusun atas gula sederhana seperti D-glukosa, D-manose, Dpentose, D-galaktose, D-Xilosa, dan beberapa Larabiosa, L-ramnosa. Hasil dari proses delignifikasi disajikan pada Tabel 1 .

Tabel 1. Komposisi kimia pulp bambu betung

\begin{tabular}{lcc}
\hline Komponen & $\begin{array}{c}\text { Pulp bambu } \\
\text { belum putih } \\
(\%)\end{array}$ & $\begin{array}{c}\text { Pulp bambu putih } \\
\mathbf{( \% )}\end{array}$ \\
\hline Ekstraktif & 0,828 & 0,198 \\
Lignin & 4,567 & 0,572 \\
Hemiselulosa & 2,465 & 1,792 \\
Alfa selulosa & 87,494 & 90,325 \\
\hline
\end{tabular}

Degradasi ekstraktif, lignin, dan hemiselulosa terjadi setelah proses delignifikasi. Penurunan komposisi yang cukup tinggi terjadi pada lignin yang mencapai $87,47 \%$ setelah proses. Hal ini menjelaskan bahwa senyawa kromofor pada pulp bambu betung dapat teroksidasi dengan baik. Sementara itu, penurunan komposisi hemiselulosa juga terjadi sebesar 27,3\% setelah proses. Penurunan komposisi komponen amorf berdampak pada perubahan

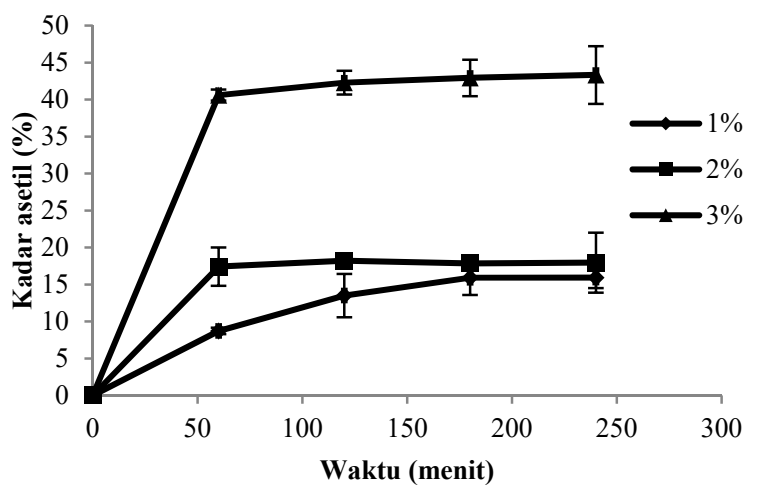

Gambar 2. Grafik hubungan kadar asetil terhadap waktu pada berbagai jumlah katalis komposisi serat secara keseluruhan sehingga alfa selulosa meningkat sebesar 3,13\%. Kandungan alfa selulosa yang cukup tinggi dapat meningkatkan peluang gugus hidroksil tersubstitusi oleh gugus asetil pada pulp bambu betung melalui proses asetilasi.

\section{Karakteristik Selulosa Terasetilasi dari Pulp Bambu Betung \\ Derajat substitusi}

Serat yang digunakan sebagai penguat pada biokomposit lebih diutamakan jika memiliki aspek rasio tinggi, dimana aspek rasio dijelaskan sebagai perbandingan panjang dengan diameter (L/D) serat. Oleh karena itu, reaksi asetilasi diharapkan hanya terjadi pada selulosa di permukaan serat. Kehadiran katalis asam pada reaksi asetilasi bertujuan untuk mengaktifkan gugus karbonil $(\mathrm{C}=\mathrm{O})$ pada asetat anhidrat, akan tetapi di sisi lain dapat menghidrolisis selulosa menjadi D-glukosa sehingga menyebabkan perubahan struktur dan sifat selulosa. Katalis asam sulfat yang digunakan pada penelitian ini adalah 1, 2, dan 3\% volume terhadap berat selulosa.

Pengaruh jumlah katalis terhadap kemampuan subtitusi gugus asetil pada selulosa dapat dilihat pada Gambar 2 dan 3. Peningkatan jumlah katalis akan meningkatkan kadar asetil seperti dijelaskan pada Gambar 2. Peninjauan pada 60 menit pertama diperoleh kadar asetil 8,71; 17,40; dan 40,61\% berturut turut untuk jumlah katalis 1, 2, dan 3\%. Semakin tinggi jumlah katalis akan mempercepat reaksi asetilasi, akan tetapi jumlah katalis yang terlalu tinggi akan menyebabkan reaksi menjadi sulit dikontrol dan juga terjadi degradasi selulosa membentuk karbohidrat yang terlarut dalam larutan sehingga tidak dapat tertahan pada saat pencucian (Bledzki dkk., 2008; Zhang dkk., 2013). Seiring dengan penambahan waktu juga memberikan peningkatan kadar asetil. Namun pada jumlah katalis $2 \%$ dan 3\% peningkatan kadar asetil tidak terjadi secara signifikan dan cenderung semakin lambat setelah waktu 120 menit.

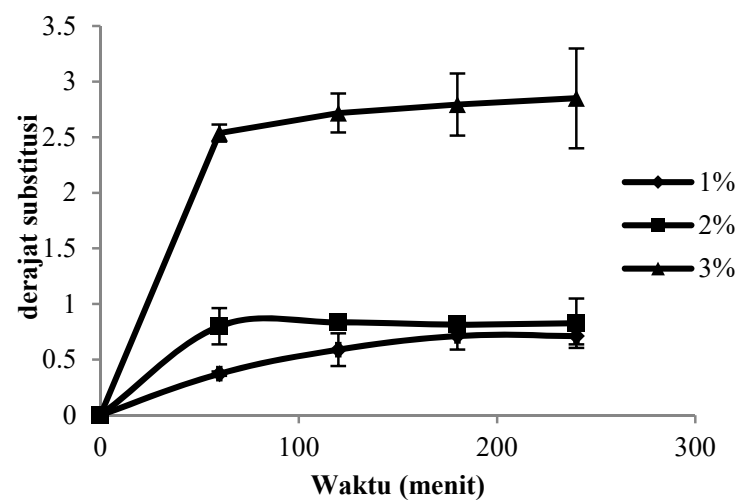

Gambar 3. Grafik hubungan derajat substitusi terhadap waktu pada berbagai jumlah katalis 
Hasil serupa diperoleh pada derajat substitusi, dimana terjadi peningkatan derajat subtitusi seiring dengan peningkatan jumlah katalis seperti dijelaskan pada Gambar 3. Peninjauan pada waktu 120 menit diperoleh hasil 0,$58 ; 0,83$; dan 2,7 berturut turut untuk jumlah katalis 1, 2, dan 3\%. Waktu reaksi lebih dari 120 menit menunjukkan derajat substitusi yang cenderung konstan terutama pada jumlah katalis 2 dan $3 \%$. Studi yang telah dilakukan oleh Zhang dkk. (2013) memberikan hasil bahwa kondisi optimum untuk reaksi asetilasi batang padi diperoleh pada suhu $60^{\circ} \mathrm{C}$ dengan waktu 2 jam. Sementara itu, ErnestSaunders dkk. (2014) menyebutkan bahwa sekitar 26\% gugus hidroksil pada MFC telah tersubtitusi dengan gugus asetil pada DS 0,77.

\section{Fourier Transform Infra Red (FT-IR)}

Gambar 4 menunjukan bahwa substitusi gugus asetil pada selulosa dapat terjadi dengan baik pada jumlah katalis 1-3\%. Kemunculan gugus spesifik asetil terjadi pada regang 1741-1746 $\mathrm{cm}^{-1}$ yang menunjukkan gugus ulur $\mathrm{C}=\mathrm{O}$, regang $1372-1373 \mathrm{~cm}^{-1}$ yang menunjukkan gugus ulur $-\mathrm{CH}_{3}$, dan regang $1240-1247 \mathrm{~cm}^{-1}$ yang menunjukkan gugus ulur C-C-O (Popescu dkk., 2012; Ernest-Saunders dkk., 2014; Ashori dkk., 2014). Pada semua selulosa terasetilasi dengan berbagai jumlah katalis tidak ditemukan serapan pada regang $1700 \mathrm{~cm}^{-1}$ yang menunjukkan bahwa produk tidak mengandung gugus karboksil $(-\mathrm{COOH})$ yang mengindikasikan hasil samping berupa asam asetat (Joonobi dkk., 2010; Rodionova dkk., 2011; Zhang dkk., 2013; Ashori dkk., 2014).

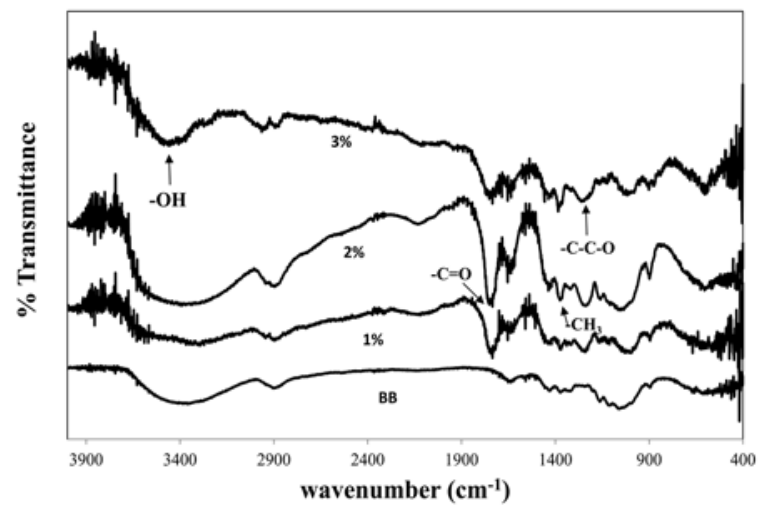

Gambar 4. Spektrogram FT-IR selulosa dan selulosa terasetilasi pada berbagai jumlah katalis

\section{Morfologi}

Morfologi selulosa terasetilasi sangat berpengaruh terhadap sifat-sifat biokomposit. Aspek rasio yang tinggi akan meningkatkan sifat mekanis biokomposit. Serat dengan aspek rasio tinggi memungkinkan sebagian besar beban yang dikenakan pada matrik dapat ditahan oleh serat yang kuat dan kaku. Interaksi serat dengan polimer semikristalin menghasilkan lapisan dengan orientasi tinggi pada permukaan (interface) serat dan matrik yang disebut transkristalisasi (TCL) yang sekaligus menunjukkan kemampuan serat sebagai bahan pembentuk inti.
Pertumbuhan TCL terjadi secara lateral sepanjang permukaan serat, maka dengan aspek rasio tinggi kristal yang terbentuk menjadi lebih kompak dan dapat meningkatkan kekuatan komposit. Menurut Albano dkk. (2003), proses asetilasi pada permukaan serat akan meningkatkan peruaraian serat dari serat bundle menjadi serat yang lebih kecil. Semakin baik peruraian serat akan memudahkan dispersi serat dalam matrik polimer. Gambar 5 menunjukkan bahwa proses asetilasi pada pulp bambu betung dapat menguraikan serat hingga jumlah katalis $2 \%$, lebih dari itu terjadi reaksi hingga ke selulosa pada badan serat setelah peruraian sehingga terjadi perubahan morfologi dimana serat menjadi partikel seperti ditunjukkan pada Gambar 5(d). Hal tersebut menjelaskan bahwa dengan jumlah katalis yang terlalu tinggi menyebabkan kerusakan struktur morfologi selulosa karena katalis asam dapat terpenetrasi hingga badan serat. Selain itu, peningkatan kekasaran pada permukaan selulosa juga terjadi pada jumlah katalis 1 dan $2 \%$. Kekasaran pada permukaan serat dapat meningkatkan luas area efektif sehingga meningkatkan area kontak terjadinya ikatan saling mengunci (interlocking) antara serat dengan matrik. Gambar 5 juga menunjukkan bahwa diameter serat berkisar 20-100 $\mu \mathrm{m}$ tidak jauh berbeda dengan sebelum perlakuan yang juga berkisar antara 20-100 $\mu \mathrm{m}$. Hal ini menjelaskan bahwa selulosa terasetilasi yang dihasilkan (1 dan 2\%) masih memiliki aspek rasio yang cukup tinggi dengan peningkatan kekasaran pada permukaan akibat terkikisnya dinding serat .
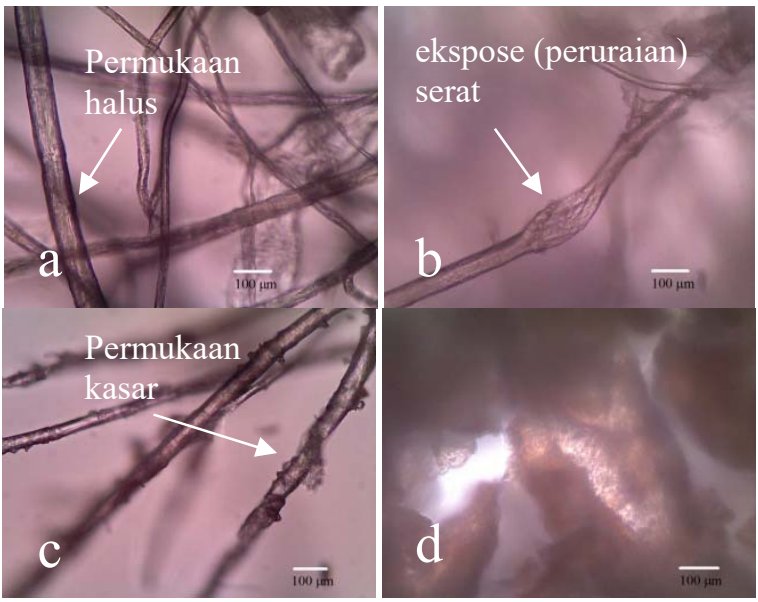

Gambar 5. Morfologi pulp bambu putih pada perbesaran 400x sebelum perlakuan (a), jumlah katalis $1 \%$ (b), $2 \%$ (c), dan $3 \%$ (d)

Reaksi asetilasi awalnya terjadi pada selulosa di permukaan serat dan peran katalis juga sebagai pemecah permukaan serat sehingga reaksi berlanjut hingga ke selulosa di badan serat (Jonoobi dkk., 2010; Rodionova dkk., 2011; Popescu dkk., 2012). Jumlah katalis semakin tinggi pada suasana asam akan menyebabkan degradasi karbohidrat berlangsung lebih cepat (Zhang dkk., 2013). Lebih jauh Yang (2008) menjelaskan bahwa semakin tinggi derajat substitusi akan mengurangi bentuk fibrous pada serat karena 
asam sulfat akan mendifusi hingga ke selulosa pada badan serat sehingga memecah ikatan hidrogen intermolekul dan merusak komponen kristalin. Studi yang telah dilakukan oleh Luz dkk. (2008) menjelaskan bahwa melalui proses asetilasi menghasilkan perubahan morfologi serat menjadi globular dan partikel sehingga menurunkan sifat mekanis komposit dengan polipropilena.

\section{Penyerapan air}

Perlakuan asetilasi pada selulosa dilakukan dalam upaya peningkatan sifat hidrofobisitas sehingga dapat meningkatkan ikatan antar muka dengan matrik polimer. Hasil pengujian penyerapan air disajikan pada Gambar 6. Pada jumlah katalis 1\% nampak penyerapan masih cukup tinggi, sementara pada $2 \%$ penurunan penyerapan air cukup banyak baik pada waktu 15, 30, dan 60 menit. Hasil yang cukup signifikan terjadi pada perlakuan asetilasi dengan katalis 3\% dimana terjadi penurunan penyerapan air yang tinggi. Hal ini dapat menjelaskan bahwa dengan peningkatan kadar asetil dan derajat substitusi, selulosa terasetilasi menjadi bersifat lebih hidrofob karena substitusi gugus asetil pada gugus hidroksil selulosa. Peningkatan gugus asetil pada selulosa memberikan pengaruh pengurangan penyerapan air mengingat gugus hidroksil sangat mudah berikatan dengan air (Nwadiogbu dkk., 2014). Krisdianto (2012) menjelaskan bahwa pengurangan gugus hidroksil pada selulosa akan mengurangi penyerapan air baik berupa uap maupun cairan.

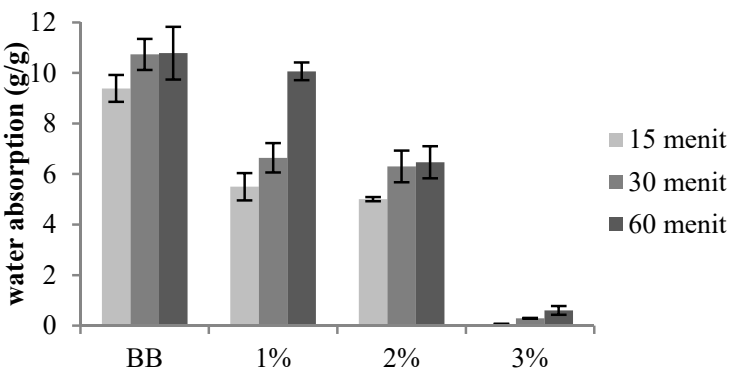

Gambar 6. Grafik penyerapan air selulosa sebelum perlakuan (BB) dan selulosa terasetilasi

\section{X-ray diffraction (XRD)}

Perlakuan asetilasi pada selulosa sangat mempengaruhi struktur kristalnya, mengingat selulosa merupakan bahan yang bersifat polimorf. Analisis XRD menjelaskan pengaruh dari perlakuan asetilasi terhadap struktur kristal suatu bahan. Gambar 7 menunjukkan bahwa selulosa sebelum perlakuan memiliki intensitas tertinggi pada sudut $2 \theta$ yaitu $15^{\circ}$ dan $21^{\circ}$ yang masing-masing menunjukkan kristalograf pada plane 101 dan 200 . Selain itu juga terdeteksi komponen amorf pada $2 \theta$ berkisar $19^{\circ}$. Hasil tersebut menunjukkan bahwa selulosa sebelum perlakuan memiliki karakteristik struktur kristal selulosa I yaitu struktur asli selulosa dengan D glukopiranosa sebagai unit monomer yang terikat pada ikatan glikosida $\beta$ 1,4, struktur bangun kristal heksagonal (Zugenmaier, 2008).

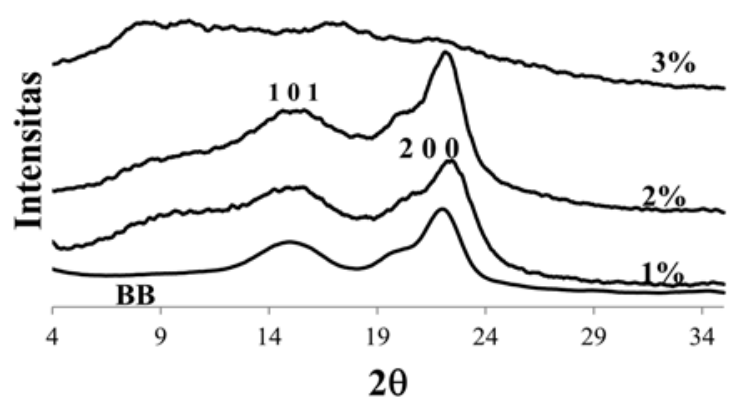

Gambar 7. Analisis XRD selulosa sebelum perlakuan dan selulosa terasetilasi pada berbagai jumlah katalis

Selulosa yang mendapatkan perlakuan asetilasi menunjukkan puncak pada sudut $2 \theta$ yang berbeda dengan selulosa sebelum perlakuan. Gambar 7 menunjukkan bahwa terdeteksi puncak pada $2 \theta$ berkisar antara $15^{\circ}$ dan $21-22^{\circ}$ untuk selulosa terasetilasi pada semua variasi jumlah katalis. Namun diperoleh hasil dimana terdeteksi puncak $2 \theta$ pada $6-8^{\circ}$ dari semua jenis variasi jumlah katalis. Hal ini dimungkinkan karena perubahan struktur kristal seperti studi yang telah dilakukan oleh Popescu dkk. (2012) yang menjelaskan bahwa kemunculan puncak pada $8^{\circ}$ menunjukkan adanya susunan kristal tidak beraturan (disorder) dari selulosa terasetilasi. Gambar 7 lebih jauh menjelaskan bahwa tidak terdapat puncak yang tajam pada jumlah katalis $3 \%$ yang menunjukkan bahwa selulosa terasetilasi bersifat lebih amorf karena proses asetilasi merusak susunan kristalin pada selulosa seperti dijelaskan oleh Widyaningsih dan Radiman (2007).

Melalui analisis XRD dapat ditentukan derajat kristalinitas suatu bahan. Derajat kristalinitas disajikan pada Tabel 2. Perlakuan asetilasi diketahui mempengaruhi penurunan derajat kristalinitas selulosa untuk semua variasi jumlah katalis. Perubahan struktur kristal serta keberadaan gugus asetil membuat selulosa bersifat lebih amorf. Selulosa terasetilasi dengan derajat subtitusi tinggi (3\%) menunjukkan derajat kristalinitas yang rendah yang menunjukkan sifat amorf. Pada penelitian ini derajat kristalinitas tertinggi untuk selulosa terasetilasi adalah pada jumlah katalis 2\% dengan nilai 80,77. Proses asetilasi memecah ikatan molekul hidrogen pada selulosa dan menggantikan dengan gugus asetil yang lebih bervolume sehingga terjadi penurunan derajat kristalisasi (Jonoobi dkk., 2010; Zhang dkk., 2013; Ashori dkk., 2014; Das dkk., 2014).

Tabel 2. Derajat kristalinitas selulosa dan selulosa terasetilasi

\begin{tabular}{lccc}
\hline Karakteristik & I (plane 200) & I amorf & \% Xc \\
\hline Pulp bambu & 336 & 64 & 84 \\
SK a & 419 & 137 & 75,36 \\
SK b & 567 & 135 & 80,77 \\
SK c & 49 & 29 & 62,82 \\
\hline
\end{tabular}




\section{Differential Scanning Calorimetry (DSC)}

Gambar 8 menunjukkan titik leleh selulosa sebelum perlakuan mencapai $354,34^{\circ} \mathrm{C}$ sedangkan setelah perlakuan asetilasi terjadi penurunan titik leleh yaitu 296,75 dan $260,75^{\circ} \mathrm{C}$ berturut turut untuk jumlah katalis 1 dan $2 \%$. Perbandingan dilakukan pada serat dan serat terasetilasi dengan morfologi fibrous yang menunjukkan bahwa terjadi penurunan titik leleh pada selulosa terasetilasi dengan penambahan jumlah katalis. Hal tersebut dimungkinkan karena perubahan struktur selulosa sehingga terjadi perubahan ketahanan panas walaupun morfologi serat masih dalam aspek rasio yang relatif tinggi.

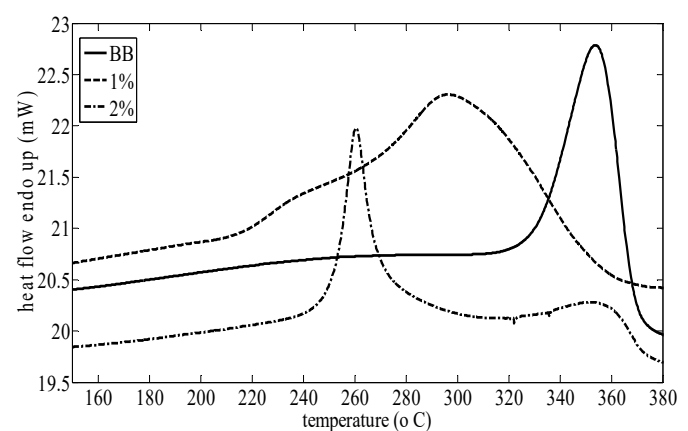

Gambar 8. Termogram DSC selulosa sebelum perlakuan dan selulosa terasetilasi pada berbagai jumlah katalis

Dari beberapa analisis yang telah dilakukan, berdasarkan pertimbangan faktor derajat subtitusi, morfologis, sifat mikroskopik struktur kristal, dan sifat panasnya untuk pembuatan biokomposit digunakan serat terasetilasi dengan jumlah katalis $2 \%$. Sementara itu waktu yang digunakan untuk reaksi asetilasi adalah 120 menit karena lebih dari itu derajat substitusi yang diperoleh cenderung sedikit mengalami peningkatan atau dapat dikatakan reaksi melambat.

\section{Sifat mekanis biokomposit Polipropilena}

Nilai dari pengujian tekuk dan tarik disajikan pada Gambar 9 dan 10. Beberapa faktor dapat mempengaruhi sifat mekanis biokomposit diantaranya jenis, ukuran, morfologi, sifat serat, dan lain-lain. Gambar 9 menunjukkan bahwa terjadi peningkatan kuat tarik dan kuat tekuk biokomposit baik dengan perlakuan maupun tanpa perlakuan dibandingkan PP murni. Kuat tarik menunjukkan kemampuan bahan menahan gaya tarik, sementara kuat tekuk menunjukkan kemampuan bahan menahan beban secara tegak lurus. Dari hasil tersebut, dapat dikatakan bahwa biokomposit dengan penambahan selulosa memiliki kemampuan untuk menahan beban yang lebih baik dibandingkan PP murni. Hal ini menjelaskan bahwa selulosa dapat berfungsi dengan baik sebagai penguat dalam matrik polipropilena.

Nilai kuat tekuk pada biokomposit tanpa perlakuan (PBB10 dan PBB20) menunjukkan sedikit peningkatan, sementara itu peningkatan cukup tinggi terjadi pada biokomposit dengan perlakuan asetilasi mencapai 76 dan $87 \%$ berturut-turut untuk PAB 10 dan PAB 20 terhadap PP murni. Sedangkan nilai kuat tarik menunjukkan hasil serupa dimana terjadi peningkatan dengan penambahan komposisi selulosa baik dengan perlakuan maupun tanpa perlakuan. Biokomposit dengan perlakuan asetilasi menghasilkan nilai kuat tarik yang lebih baik dengan peningkatan sekitar 24 dan $69 \%$ masing-masing untuk PAB 10 dan PAB 20 terhadap PP murni. Hal ini semakin menunjukkan bahwa dengan perlakuan asetilasi pada permukaan serat akan mengakibatkan serat menjadi lebih hidrofob sehingga meningkatkan ikatan antar muka dan dispersi dengan matrik polipropilena. Selain itu, dengan permukaan yang lebih kasar juga akan meningkatkan interlocking antara permukaan serat dengan matrik.

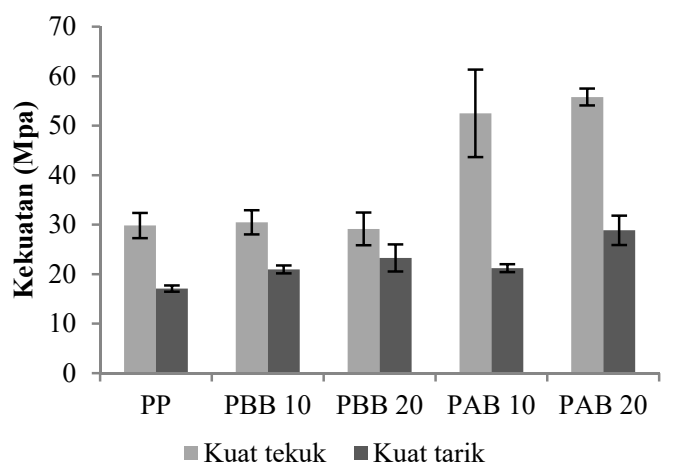

Gambar 9. Nilai kuat tekuk dan kuat tarik PP dan biokomposit pada komposisi selulosa $10 \%$ dan $20 \%$

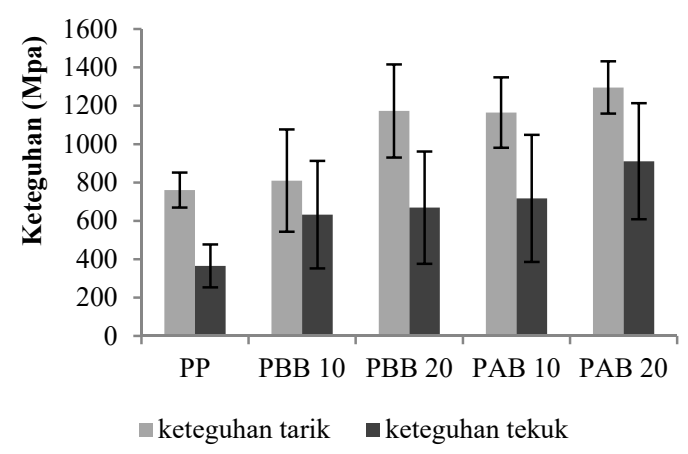

Gambar 10. Nilai keteguhan tekuk dan keteguhan tarik PP dan biokomposit pada komposisi selulosa $10 \%$ dan $20 \%$

Keteguhan tarik dan tekuk biokomposit menunjukkan peningkatan dibandingkan dengan PP murni seperti dijelaskan pada Gambar 10. Keteguhan tarik meningkat hingga 53 dan $70 \%$ sedangkan keteguhan tekuk mencapai 96 dan 149\% berturut-turut untuk PAB10 dan PAB20 dibandingkan PP. Peningkatan komposisi serat baik tanpa perlakuan maupun dengan perlakuan dari 10 menjadi $20 \%$ juga memberikan peningkatan nilai.

Gambar 11 adalah penampakan patahan melintang dari sample uji kegagalan (fracture) untuk tensile. Analisis SEM menjelaskan lebih dalam bahwa 
dispersi selulosa kurang baik pada komposit dengan selulosa tanpa perlakuan ditunjukkan dengan banyaknya penarikan serat $(a, b)$ bahkan terjadi aglomerasi dibandingkan dengan pada komposit dengan perlakuan (c, d). Hasil dari penelitian Luz dkk. (2008) menunjukkan terjadinya penurunan kuat tarik pada komposit PP dengan serat bagas terasetilasi, jumlah katalis asam sulfat 3,3\%, karena serat selulosa berubah secara morfologi menjadi globural, sedangkan kuat tekan terjadi peningkatan hanya 9$10 \%$ dibandingkan PP murni. Serat flax yang mendapatkan perlakuan asetilasi masih berbentuk serat bundle dan memberikan peningkatan kuat tarik hingga $40 \mathrm{MPa}(33 \%)$ sedangkan kuat tekuk mencapai $60 \mathrm{MPa}(9 \%)$ dengan komposisi serat 30\% (Bledzki dkk., 2008). Hal tersebut semakin menguatkan bahwa morfologi serat yang digunakan sebagai penguat pada matrik PP sangat berpengaruh pada kekuatan komposit.

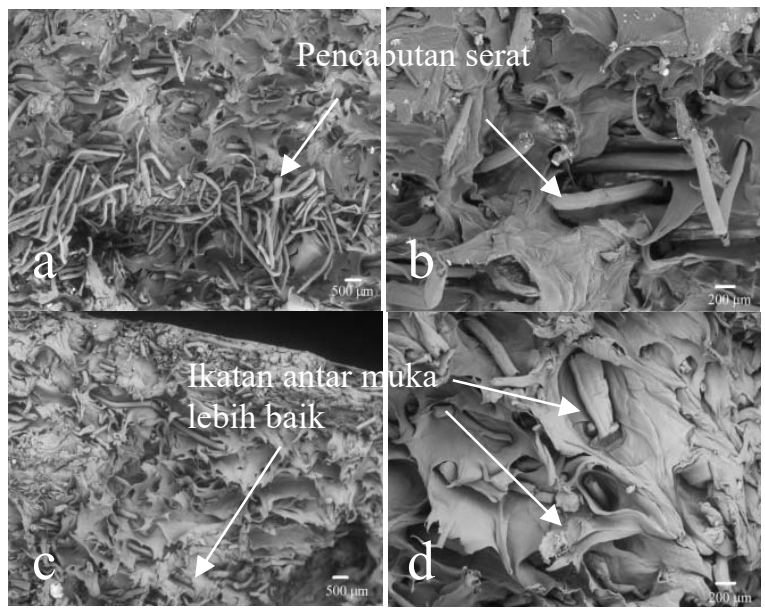

Gambar 11. Morfologi SEM patahan sample uji tensile PBB 10 perbesaran 150x (a), 500x (b), PAB 10 perbesaran 150x (c), 500x (d)

Pemanfaatan serat bambu sebagai penguat pada matrik PP telah dilakukan oleh beberapa peneliti. Penggunaan maleic anhydride graft polypropylene (MAPP) sering digunakan sebagai coupling agent dikarenakan memiliki dua gugus fungsi aktif. Peningkatan kuat tarik mencapai 49,28\% dan keteguhan tarik hingga $62,55 \%$ terjadi pada biokomposit serat bambu dibandingkan dengan PP murni (Chattopadhyay dkk., 2010). Serat mikro terfibrilasi (MFC) dari bambu juga memberikan peningkatan sebesar 90,26\% untuk kuat tekuk dan 1,1 kali untuk keteguhan tekuk pada biokomposit PP (Subyakto dkk., 2011). Interaksi antara selulosa dengan matrik terjadi pada permukaan, sehingga perubahan fisik maupun kimia dapat memberikan hasil yang berbeda. Modifikasi kimia dengan asetilasi pada selulosa diketahui menghasilkan sifat mekanis biokomposit PP yang mendekati dengan perlakuan MAPP. Mekanisme ikatan saling bertaut antara selulosa dengan MAPP dapat dikatakan hampir sama dengan mekanisme interaksi selulosa terasetilasi pada permukaan yang juga menghasilkan peningkatan kekasaran permukaan serat. Perlakuan kimia pada pengisi dapat meningkatkan interaksi dengan matrik akibat peningkatan keterbasahan dan ikatan antar muka yang berdampak pada peningkatan kekuatan komposit (Harper, 2006). Menurut Somnuk (2007) modifikasi kimia pada permukaan serat dapat menginisiasi pertumbuhan TCL yang mengindikasikan serat efektif sebagai bahan pembentuk inti.

Analisis XRD dapat menjelaskan struktur kristal suatu bahan akibat berbagai perlakuan dan proses. Gambar 12 menyajikan hasil analisis XRD untuk PP murni dan biokomposit dengan selulosa terasetilasi (PAB 10 dan PAB 20). Puncak difraksi ditemukan pada plane 110,130 , dan 200 yaitu pada $2 \theta$ berturut-turut $13^{\circ}, 16^{\circ}$, dan $21^{\circ}$ untuk PP murni dan biokomposit PAB10 maupun PAB20. Fase $\beta$ pada komposit dapat dideteksi pada difraksi plane 300 (Mi dkk., 1997). Kemunculan puncak difraksi pada plane 300 untuk biokomposit PAB 10 maupun PAB 20 menunjukkan kemunculan fase $\beta$ yang tidak nampak pada PP murni. Pembentukan fase $\beta$ pada proses kritalisasi biokomposit diusahakan untuk meningkatkan sifat mekanisnya. Hasil tersebut lebih jauh menjelaskan bahwa selulosa terasetilasi dapat berfungsi sebagai bahan pembentuk inti pada PP. Selain itu, hasil tersebut menguatkan terjadinya peningkatan sifat mekanis seperti yang tersaji pada Gambar 9 dan 10. Li dkk. (2004) menjelaskan bahwa pembentukan fase $\beta$ pada PP isotaktik menunjukkan proses transkristalisasi pada permukaan serat yang dapat meningkatkan sifat mekanis komposit.

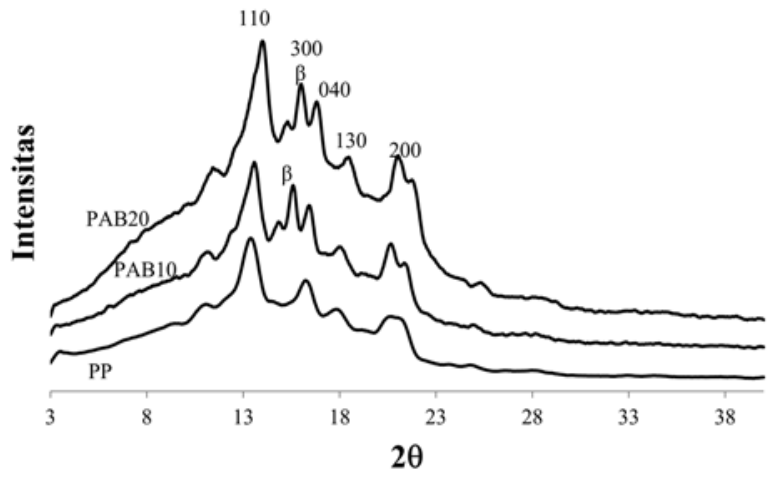

Gambar 12. Analisis XRD polipropilena murni dan biokomposit dengan selulosa terasetilasi

\section{KESIMPULAN}

Kondisi optimum proses modifikasi kimia selulosa pada permukaan pulp bambu betung melalui reaksi asetilasi yaitu pada jumlah katalis asam sulfat 2\% dengan waktu reaksi 120 menit. Pada kondisi operasi tersebut diperoleh kadar asetil 18,19\% dengan kemunculan gugus spesifik pada regang $1750 \mathrm{~cm}^{-1}$ $(\mathrm{C}=\mathrm{O}), 1375 \mathrm{~cm}^{-1}, 1239 \mathrm{~cm}^{-1}$ (C-C-O) serta morfologi yang masih berbentuk serat (fibrous) yang bersifat lebih hidrofob dengan derajat kristalinitas relatif tinggi pada $80,77 \%$ sehingga dapat digunakan sebagai 
penguat dalam komposit PP. Penambahan serat terasetilasi mampu meningkatkan sifat mekanis biokomposit terutama pada kuat tekuk, kuat tekan, dan keteguhan tekuk dibandingkan dengan PP dan biokomposit dengan selulosa tanpa perlakuan. Peningkatan komposisi selulosa terasetilasi sampai $20 \%$ dalam matrik PP mampu meningkatkan sifat mekanisnya. Selulosa terasetilasi dari pulp bambu betung dapat berfungsi sebagai bahan pembentuk inti pada biokomposit dimana terbentuk fase $\beta$ yang menunjukkan bahwa terjadi transkritalisasi pada permukaan serat.

\section{UCAPAN TERIMA KASIH}

Penulis mengucapkan terima kasih kepada Kemenristek-Dikti karena telah memberikan pendanaan pada penelitian ini melalui program Beasiswa Pasca Sarjana. Ucapan terima kasih penulis ucapkan kepada pihak-pihak yang telah membantu terutama laboran dan teknisi diantaranya Sudarmanto, Fazar Akbar, Zamroni, dan Pandu.

\section{DAFTAR PUSTAKA}

Abdul, H.P.S., (2014), Production and Modification of Nanofibrillated Cellulose using Various Mechanical Process, Carbohydrate Polymer, 99, pp. 649-665.

Abdulkhani, A., Hosseinzadeh, J., and Ashori, A., (2014), Preparation and Characterization of Modified Cellulose Nanofiber Reinforced PLA Nanocomposite, Polymer Testing, 35, pp. 73-79

Albano, C., Gonzales, J., Ichazo, M., Velasco, N., Guevara, J., and Mantia, F.L., (2003), Thermal Stability of Polypropylene with Acetylated Sisal Fiber: Romero Garcia Kinetic Method, Polymer Bulletin, 51, pp. 245-254.

Al-Oqla, F. and Sapuan, S.M., (2014), Natural Fiber Reinforced Polymer Composites in Industrial Applications: Feasibility of Date Palm Fibers for Sustainable Automotive Industry, Journal of Cleaner Production, 66, pp. 347-354.

Ashori, A., Babaee, M., Jonoobi, M., and Hamzeh, Y., (2014), Solvent Free Acetylation of Cellulose Nanofibers for Improving Compatibility and Dispersion, Carbohydrate Polymer, 102, pp. 369-375.

Bledzki, A.K., Mamun, A.A., Lucka-Gabor, M., and Gutowski, V.S., (2008), The Effect of Acetylation on Properties of Flax Fibre and its Polypropylene Composites, Express Polymer Letters, 2(6), pp. 413422

Chattopadhyay, S.K., Khandal, R.K., Uppaluri, R., and Ghoshal, A.K., (2010), Bamboo Fiber Reinforced Polypropylene Composites and their Mechanical, Thermal, and Morphological Properties, Journal of Applied Polymer Science, 119, pp. 1619-1619.
Das, A.M., Ali, A.A., and Hazarika, M.P., (2014), Synthesis and Characterization of Cellulose Acetate from Rice Husk: Eco-Friendly Condition, Carbohydrate Polymer, 112, pp. 342-349.

Ernest-Saunders, R., Pawlak, J.J., and Lee, J.M., (2014), Properties of Surface Acetylated Microfibrillated Cellulose Relative to Intra and Inter Fibril Bonding, Cellulose, 21, pp. 1541-1552.

Fatriasai, W. dan Hermiati, E., (2008), Analisis Morfologi Serat dan Sifat Fisis-Kimia pada Enam Jenis Bambu Sebagai Bahan Baku Pulp dan Kertas, Jurnal Ilmu dan Teknologi Hasil Hutan, 1(2), hal. 6772 .

Gaol, M.L., Sitorus, R., Yanthi, S., Surya, I., dan Manurung, R., (2013), Pembuatan Selulosa Asetat dari Alfa Selulosa Tandan Kosong Kelapa Sawit, Jurnal Teknik Kimia USU, 2 (3), hal. 33-39.

Harper, C., (2006), Handbook of Plastics Technologies, Mc-Graw Hill Inc. USA, p. 12

Holbery, J. and Houston, D., (2006), Natural Fiber Reinforced Polymer Composites in Automotive Applications, JOM, pp. 80-86.

Hufenbagh, W., Bohm, R., Thieme, M., Winkler, A., Mader, E., Rausch, J., and Schade, M., (2011), Polypropylene/Glass Fibre 3D Textile Reinforced Composites for Automotive Applications, Material and Design, 32, pp. 1468-1476.

Jonoobi, M., Harun, J., Mathew, A.P., Hussein, M.Z., and Oksman, K., (2010), Preparation of Cellulose Nanofibers with Hydrophobic Surface Characteristic, Cellulose, 17, pp. 299-307.

Kompella, M.K. and Lambros, J., (2002), Micromechanical Characterization of Cellulose Fibers, Polymer Testing, 21, pp. 523-530.

Krisdianto, (2012), Pengaruh Asetilasi Terhadap Penyerapan Uap Air pada Dua Jenis Kayu Tropis, Jurnal Penelitian Hasil Hutan, 30 (2), hal. 94-99.

Li, H., Xiuqin, Z., Yongxin, D., Dujin, W., Lin, L., and Shouke, Y., (2004), Influence of Crystallization Temperature on the Morphologies of Isotactic Polypropylene Single-Polymer Composite, Polymer, 45, pp. 8059-8065.

Li, X., Lope, G.T., and Panigrahi, S., (2007), Chemical Treatments of Natural Fiber for Use in Natural Fiber-Reinforced Composites (A Review), Journal Polymer Environemnt, 15, pp. 25-33.

Liu, D., Song, J., Anderson, D.P., Chang, P.R., and Hua, Y., (2012), Bamboo Fiber and its Reinforced Composites: Structure and Properties, Cellulose, 19, pp. 1449-1480. 
Luz, S.M., Tio, D.J., Rocha, G.J.M., Goncalves, A.R., and Del Arvo, A.P., (2008), Cellulose and Cellulignin from Sugarcane Bagasse Reinforced Polypropylene Composites: Effect of Acetylation on Mechanical and Thermal Properties, Composites Part A, 39, pp. 13621369.

Mi, Y., Chen, X., and Guo, Q., (1997), Bamboo Fiber Reinforced Polypropylene Composites: Crystallization and Interfacial Morphology, John Wiley and Sons, pp. 1267-1273

Nwadiogbu, J.O., Okoye, P.A.C., Ajiwe, V.I., and Nnaji, N.J.N., (2014), Hydrophobic Treatment of Corn Cob by Acetylation: Kinetics and Thermodynamic Studies, Journal of Environmental Chemical Engineering, 2, pp. 1699-1704.

Popescu, C., Larsson, P.T., Olaru, N., and Vasile, C., (2012), Spectroscopy Study of Acetylated Kraft Pulp Fibers, Carbohydrate Polymer, 88, pp. 530-536.

Ramsden, M.J. and Blake, F.S.R., (1997), A Kinetic Study of the Acetylation of Cellulose, Hemicellulose, and Lignin Components in Wood, Wood Science and Technology, 31, pp. 45-50.

Rodionova, G., Lenes, M., and Eriksen, G., (2011), Surface Chemical Modification of Microfibrillated Cellulose: Improvement of Barrier Properties for Packaging Applications, Cellulose, 18, pp. 127-134.

Somnuk, U., (2007), Studies of Crystallization of Natural Fibers-Polypropylene Composites, Thesis, Suranaree University of Technology.

Subyakto, Hermiati, E., Masruchin, N., Ismadi, and Subiyanto, B., (2011), Preparation of Micro/nano Fibers of Betung Bamboo (Dendrocalamus asper) and
Development of their Biocomposites, Prosiding Seminar Internasioanal Bambu, pp. 87-99.

Thielemans. B.L.W., Dufresne, A., Chaussy, D., and Belgacem, M.N., (2008), Surface Functionalization of Cellulose Fibers and their Incorporation on Renewable Polymer Matrices, Composites Science and Technology, 68, pp. 3193-3201.

Widyaningsih, S. dan Radiman, C.L., (2007), Pembuatan Selulosa Asetat dari Pulp Kenaf (Hibiscus cannabius), Molekul, 2(1), hal. 13-16.

Wildan, A., (2010), Studi Proses Pemutihan Serat Kelapa sebagai Reinforced Fiber, Tesis, Universitas Diponegoro

Wise, L.E., Murphy, M., and D'Addieco, A.A., (1946), Chlorite Holocellulose, its Fraction and Bearing on Summative Wood Analysis and Studies on the Hemicelluloses, Paper Trade Journal, 122, pp. 1119.

Yang, Z., Xu, S., Ma, X., and Wang, S., (2008), Characterization and Acetylation Behaviour of Bamboo Pulp, Wood Science Technology, 42, pp. 621632.

Zhang, G., Huang, K., Jiang, X., Huang, D., and Yang, Y., (2013), Acetylation of Rice Straw for Thermoplastic Applications, Carbohydrate Polymer, 96, pp. 218-226.

Zimmermann, T., Pohler, E., and Geiger, T., (2004), Cellulose Fibrils for Polymer Reinforcement, Advanced Engineering Materials, 6(9), pp. 754-761.

Zugenmaier, P., (2008), Crystalline Cellulose and Cellulose Derivatives: Characterization and Structure, John Wiley and Sons, pp. 31. 